\title{
Considerations Associated with Reactor Technology Selection for the Next Generation Nuclear Plant Project
}

The INL is a

U.S. Department of Energy National Laboratory

operated by

Battelle Energy Alliance

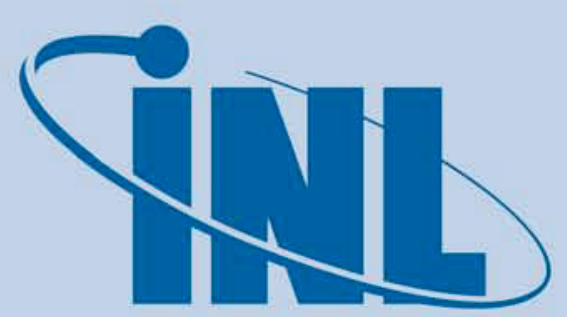

Idaho National Laboratory
September 2010

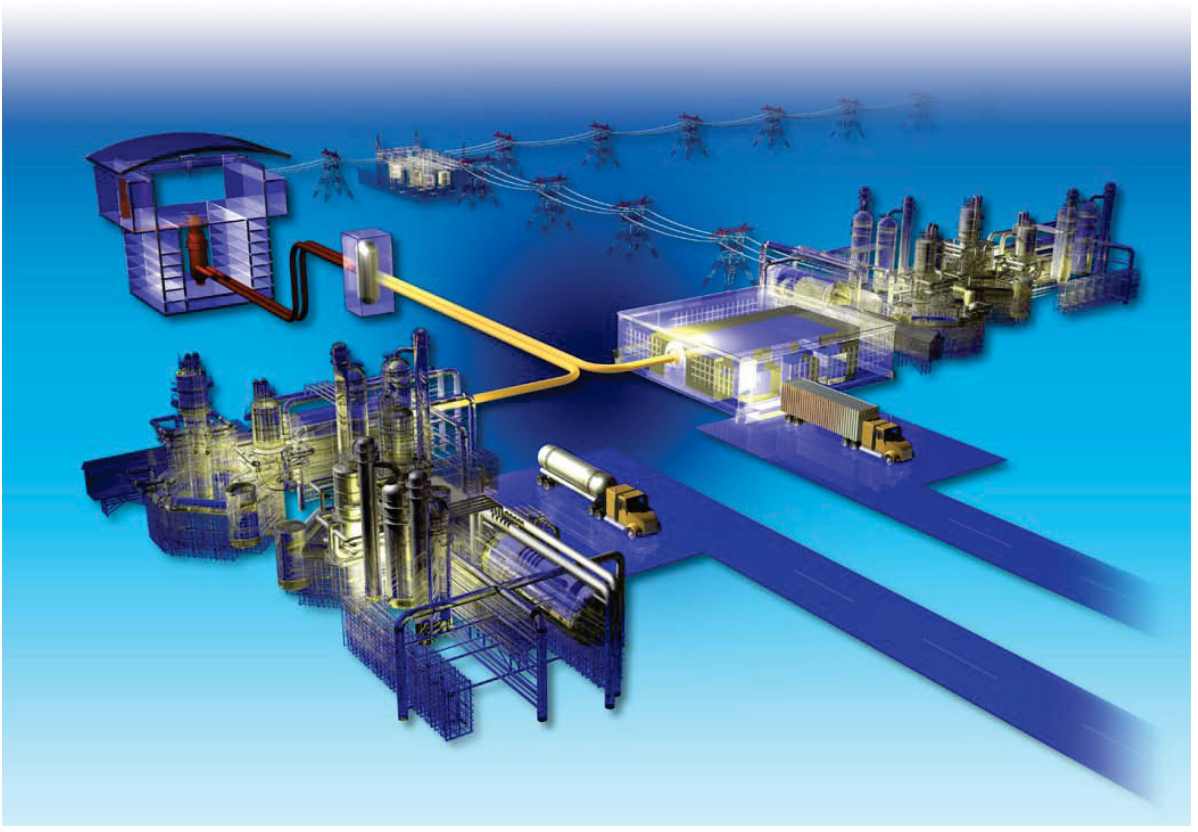




\section{DISCLAIMER}

This information was prepared as an account of work sponsored by an agency of the U.S. Government. Neither the U.S. Government nor any agency thereof, nor any of their employees, makes any warranty, expressed or implied, or assumes any legal liability or responsibility for the accuracy, completeness, or usefulness, of any information, apparatus, product, or process disclosed, or represents that its use would not infringe privately owned rights. References herein to any specific commercial product, process, or service by trade name, trade mark, manufacturer, or otherwise, does not necessarily constitute or imply its endorsement, recommendation, or favoring by the U.S. Government or any agency thereof. The views and opinions of authors expressed herein do not necessarily state or reflect those of the U.S. Government or any agency thereof. 


\section{Considerations Associated with Reactor Technology Selection for the Next Generation Nuclear Plant Project}

September 2010

Idaho National Laboratory Next Generation Nuclear Plant Project Idaho Falls, Idaho 83415

Prepared for the

U.S. Department of Energy Office of Nuclear Energy Under DOE Idaho Operations Office

Contract DE-AC07-05ID14517 

Next Generation Nuclear Plant Project

Considerations Associated with Reactor Technology Selection for the Next Generation Nuclear Plant Project

INL/EXT-10-19838

September 2010

Approved by:

28.a. Fibs

NGNP Project Director

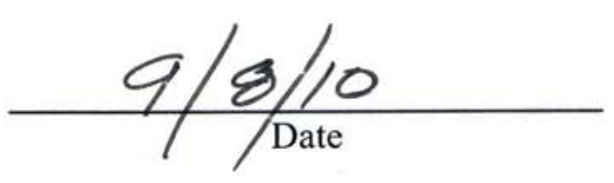





\begin{abstract}
Alternative reactor technologies have been evaluated to determine the technology that best fulfills the functional and performance requirements of the targeted energy applications and market. Unlike the case of electric power generation, where the reactor performance is primarily expressed in terms of economics, the targeted energy applications involve industrial applications that have specific needs in terms of acceptable heat transport fluids and the associated thermodynamic conditions. The alternative reactor technologies must provide operational and performance capabilities that fulfill the needs of the end user.
\end{abstract}




\section{CONTENTS}

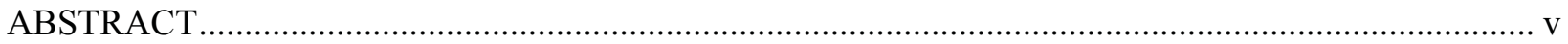

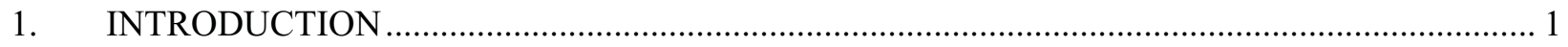

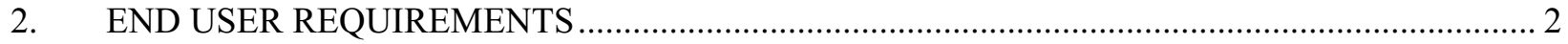

3. CAPABILITIES OF ALTERNATIVE REACTOR TECHNOLOGIES ....................................... 3

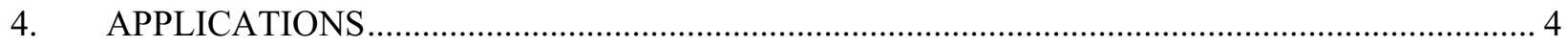

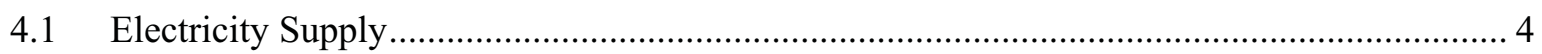

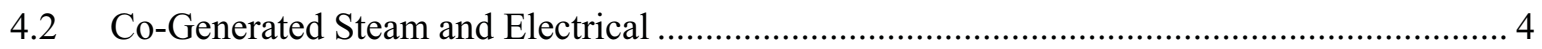

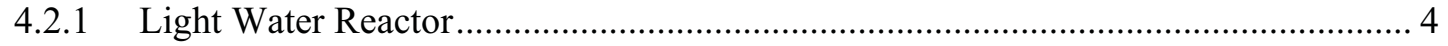

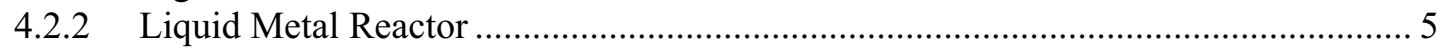

4.2.3 Energy Cost Differences for LWR and LMR applications .................................... 6

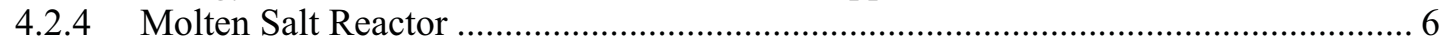

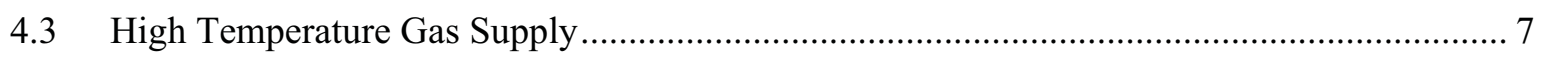

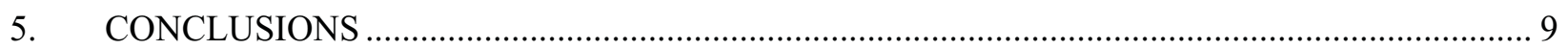

5.1 Prior Decisions Made on the NGNP Technology …..................................................... 9

FIGURES

Figure 1. Application of an LWR with a natural gas boiler for steam and electricity production............... 4

Figure 2. Application of an LMR steam generator with a natural gas fired superheater for steam

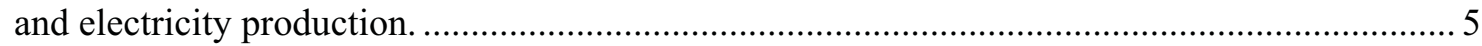

Figure 3. Effect of natural gas price on co-generated energy costs for LWR and LMR based

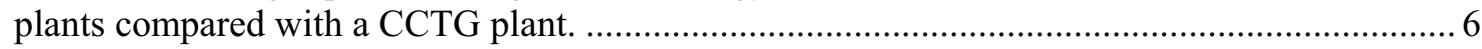

Figure 4. Application of LWR, LMR and MSR technologies to supply of high temperature

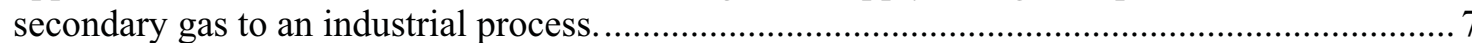

Figure 5. Comparison of the price of high temperature gas for different applications of nuclear reactor technologies.

\section{TABLES}

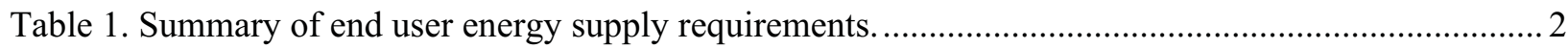

Table 2. Relative energy supplied from the reactor plant and the natural gas fired heat exchanger (600 MWth plant supplying $925^{\circ} \mathrm{C}$ gas). 


\section{Considerations Associated with Reactor Technology Selection for the Next Generation Nuclear Plant Project}

\section{INTRODUCTION}

At the inception of the Next Generation Nuclear Plant (NGNP) Project and during predecessor activities, alternative reactor technologies have been evaluated to determine the technology that best fulfills the functional and performance requirements of the targeted energy applications and market. Unlike the case of electric power generation where the reactor performance is primarily expressed in terms of economics, the targeted energy applications involve industrial applications that have specific needs in terms of acceptable heat transport fluids and the associated thermodynamic conditions. Hence, to be of interest to these industrial energy applications, the alternative reactor technologies are weighed in terms of the reactor coolant/heat transport fluid, achievable reactor outlet temperature, and practicality of operations to achieve the very high reliability demands associated with the petrochemical, petroleum, metals, and related industries. These evaluations have concluded that the high temperature gas-cooled reactor (HTGR) can uniquely provide the required ranges of energy needs for these target applications, do so with promising economics, and can be commercialized with reasonable development risk in the time frames of current industry interest, i.e., within the next 10 to 15 years.

The NGNP Project, under the direction of the Department of Energy (DOE), has been taking the steps necessary to commercialize the high temperature gas-cooled reactor (HTGR) technology as an energy source for industrial applications. The HTGR technology is intended to be used in place of burning fossil fuels with the objectives of reducing energy price volatility associated with the use of these fuels, improving energy security by reducing the need to import fossil fuels, and reducing $\mathrm{CO}_{2}$ emissions from the burning of these fuels. 


\section{END USER REQUIREMENTS}

The following summarize the energy needs based on the NGNP Project collaborating with industrial end users and in performing several assessments of the technical and economic viability of integrating the HTGR technology with the industrial processes, including supplying the following:

- Supply of steam, electricity, and high temperature fluid (e.g., He, He-N, air) for facility use

- Supply of steam for oil sands bitumen recovery. Supply of electricity to support facility operations and supply of hydrogen for upgrading the bitumen have also been identified as potential applications of the HTGR technology.

- Electricity using several different power conversion systems

- Hydrogen via high temperature steam electrolysis and steam methane reforming

- Ammonia and ammonia derivatives, (e.g., urea, ammonium nitrate, fertilizer)

- Coal and natural gas conversion to diesel fuel, gasoline and synthetic feedstocks

Table 1 summarizes the range of energy supply characteristics identified in these evaluations.

Table 1. Summary of end user energy supply requirements.

\begin{tabular}{|c|c|c|c|c|}
\hline $\begin{array}{c}\text { Reactor Outlet } \\
\text { Temperature }\end{array}$ & Plant Rating & $\begin{array}{c}\text { Supplied Steam } \\
\text { Conditions }\end{array}$ & $\begin{array}{c}\text { Electricity } \\
\text { Requirements }\end{array}$ & $\begin{array}{l}\text { High Temperature } \\
\text { Fluid Conditions }\end{array}$ \\
\hline 750 to $950^{\circ} \mathrm{C}$ & $\begin{array}{l}250 \text { to } \\
6,900 \mathrm{MWth}\end{array}$ & $\begin{array}{l}>4,000 \text { psig for } \\
\text { supercritical } \\
\text { applications, } \\
2,500 \text { psig for } \\
\text { subcritical } \\
\text { applications } \\
540 \text { to } 630^{\circ} \mathrm{C}\end{array}$ & $\begin{array}{l}\text { Up to } 2,500 \mathrm{MWe} \\
\text { investigated to- } \\
\text { date. As a supply to } \\
\text { the electrical grid a } \\
\text { wide range is } \\
\text { possible depending } \\
\text { on the location. }\end{array}$ & $\begin{array}{l}700 \text { to } 925^{\circ} \mathrm{C} \\
54 \text { to } 762 \mathrm{MWth}\end{array}$ \\
\hline
\end{tabular}




\section{CAPABILITIES OF ALTERNATIVE REACTOR TECHNOLOGIES}

The capabilities of light water cooled reactor (LWR), molten salt cooled reactor (MSR), liquid metal cooled reactor (LMR) and HTGR technologies important to industrial energy end users are summarized below. In considering use of these technologies for industrial applications, the most important characteristics are the reactor outlet temperature and the primary heat transport fluid or coolant and secondary heat transport fluid, typically steam or high temperature gas. As shown Table 1 high reactor outlet temperatures in the range 750 to $950^{\circ} \mathrm{C}$ are required to satisfy all end user requirements evaluated to-date. The following summarizes the achievable reactor outlet temperatures for these technologies:

- Light water cooled reactor

$350^{\circ} \mathrm{C}$

- Liquid metal cooled reactor

$500^{\circ} \mathrm{C}$

- Molten salt cooled reactor

$860^{\circ} \mathrm{C}$

- High temperature gas-cooled reactor

$950^{\circ} \mathrm{C}$

Supplemental heating will be required in most cases where LWR, LMR, and MSR technologies are applied to achieve the upper ranges of steam pressure and temperature conditions and the high temperature gas conditions $-925^{\circ} \mathrm{C}$-needed by the industrial end users. Supplemental heating would use firing of fossil fuels, (e.g., natural gas or waste gas) to increase the outlet temperatures of these reactor technologies as required to meet end user requirements. The HTGR technology has the capability of achieving all of the requirements without any supplemental heat. The amount of supplemental heating for other reactor technologies varies depending on the application and which other technology is applied. The following evaluates two specific applications that are typical in industrial facilities. 


\section{APPLICATIONS}

The end user requirements show that plant designs are required to supply electricity, steam, and high temperature gas to industrial facilities to cover the range of applications identified to the time of this writing for use of the HTGR technology. The HTGR has been shown to be capable of satisfying industrial energy process requirements for all of these applications. This section evaluates the use of the LWR, LMR, and MSR technologies in these applications. Where necessary, natural gas supplemental firing is assumed.

\subsection{Electricity Supply}

All of these technologies can be used to generate electricity. They will differ in the economics, i.e., the price of electricity.

\subsection{Co-Generated Steam and Electrical}

\subsubsection{Light Water Reactor}

In co-generated steam turbine generator applications, the LWR outlet temperatures are not adequate to reach the typical steam pressures $(2,500$ psig to above supercritical $)$ and temperatures $\left(540\right.$ to $\left.630^{\circ} \mathrm{C}\right)$ required in most industrial applications. If a LWR is to be applied in a typical steam and electrical supply application, supplemental firing (e.g., using natural gas) would be required to achieve the required conditions. Figure 1 illustrates a typical configuration for a subcritical 2,000 MWth plant supplying cogenerated steam and electricity to an industrial facility at a steam temperature of $565^{\circ} \mathrm{C}\left(1050^{\circ} \mathrm{F}\right)$.

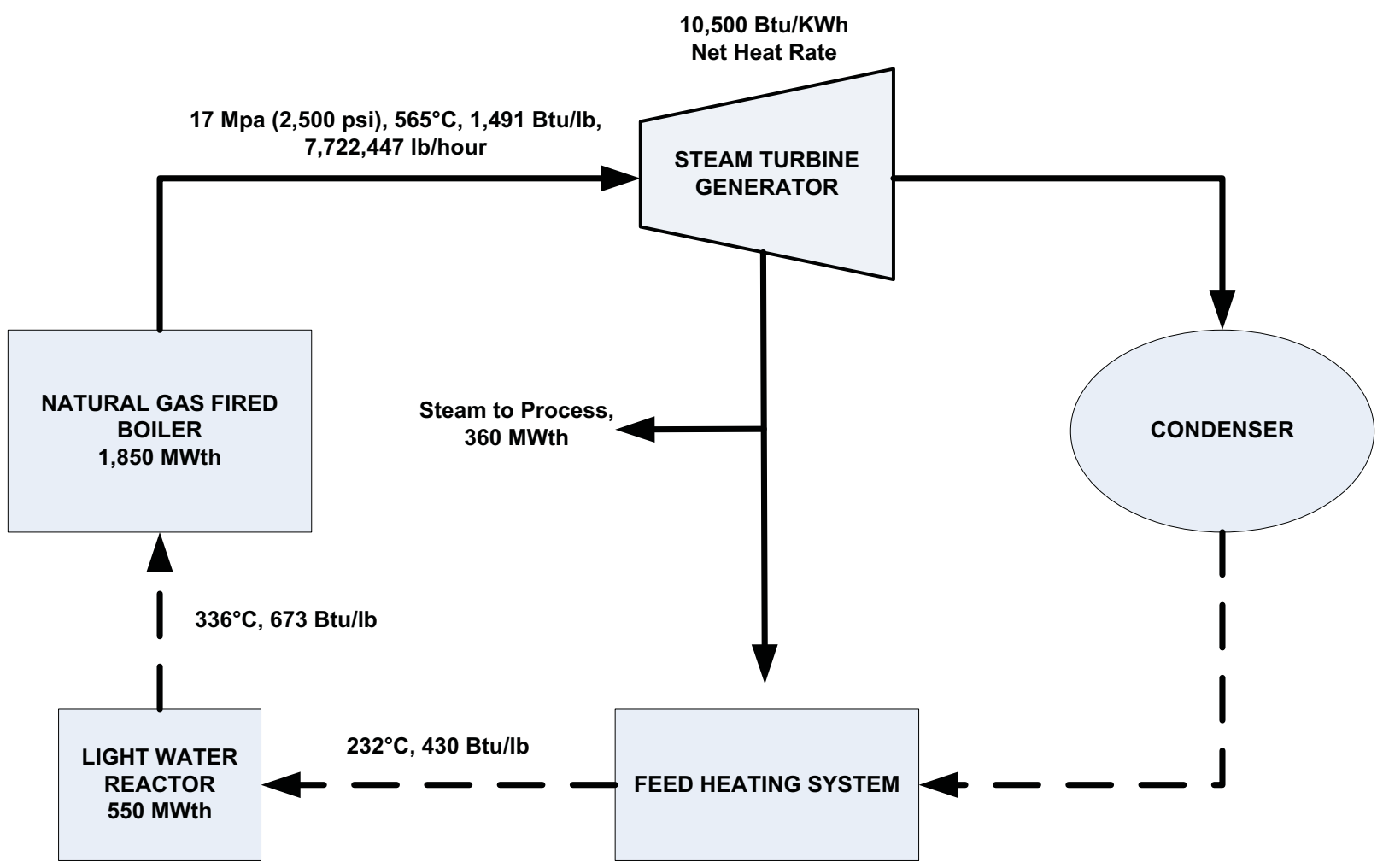

Figure 1. Application of an LWR with a natural gas boiler for steam and electricity production. 
As shown in Figure 1, the LWR is used to preheat feed to a natural gas fired boiler to within $\sim 14^{\circ} \mathrm{C}$ of the reactor outlet temperature or $336^{\circ} \mathrm{C}$. The rest of the heat input is supplied in a natural gas fired steam generator and superheater. To maximize efficiency of a typical steam turbine power Rankine cycle the feed water temperature from that cycle would be in the range of $232^{\circ} \mathrm{C}$. The LWR would then be used to add $104^{\circ} \mathrm{C}$ to the feed temperature before entering the boiler. As shown in Figure 1 this heat addition requires an LWR rating of $550 \mathrm{MWth}$. The balance of the heating would be completed with a 1,850 MWth natural gas fired boiler. In this case about $78 \%$ of the heat required would be supplied by the natural gas boiler. The economics for this small fraction of energy input from the LWR would require an energy price increase of $\sim 30 \%$ compared with a HTGR or CCGT. ${ }^{\text {a }}$ In this configuration substantial natural gas firing is required. Therefore, this configuration does not address energy price volatility or the full scope of emission reduction objectives.

\subsubsection{Liquid Metal Reactor}

If a LMR were applied in this application it would be capable of achieving the necessary steam pressure but would not achieve the $565^{\circ} \mathrm{C}$ steam temperature. A natural gas fired superheater could be used to increase the outlet temperature from that achievable in the LMR, (i.e., $\sim 480^{\circ} \mathrm{C}$ ). Figure 2 shows a potential configuration for this application. In this case the natural gas heat energy input accounts for $10 \%$ of the total energy demand. The breakeven cost of natural gas at which this option would be viable depends on the cost for the LMR. If the LMR has a comparable or higher cost compared with the HTGR the HTGR is a more cost effective application since the supplemental heating is not required.

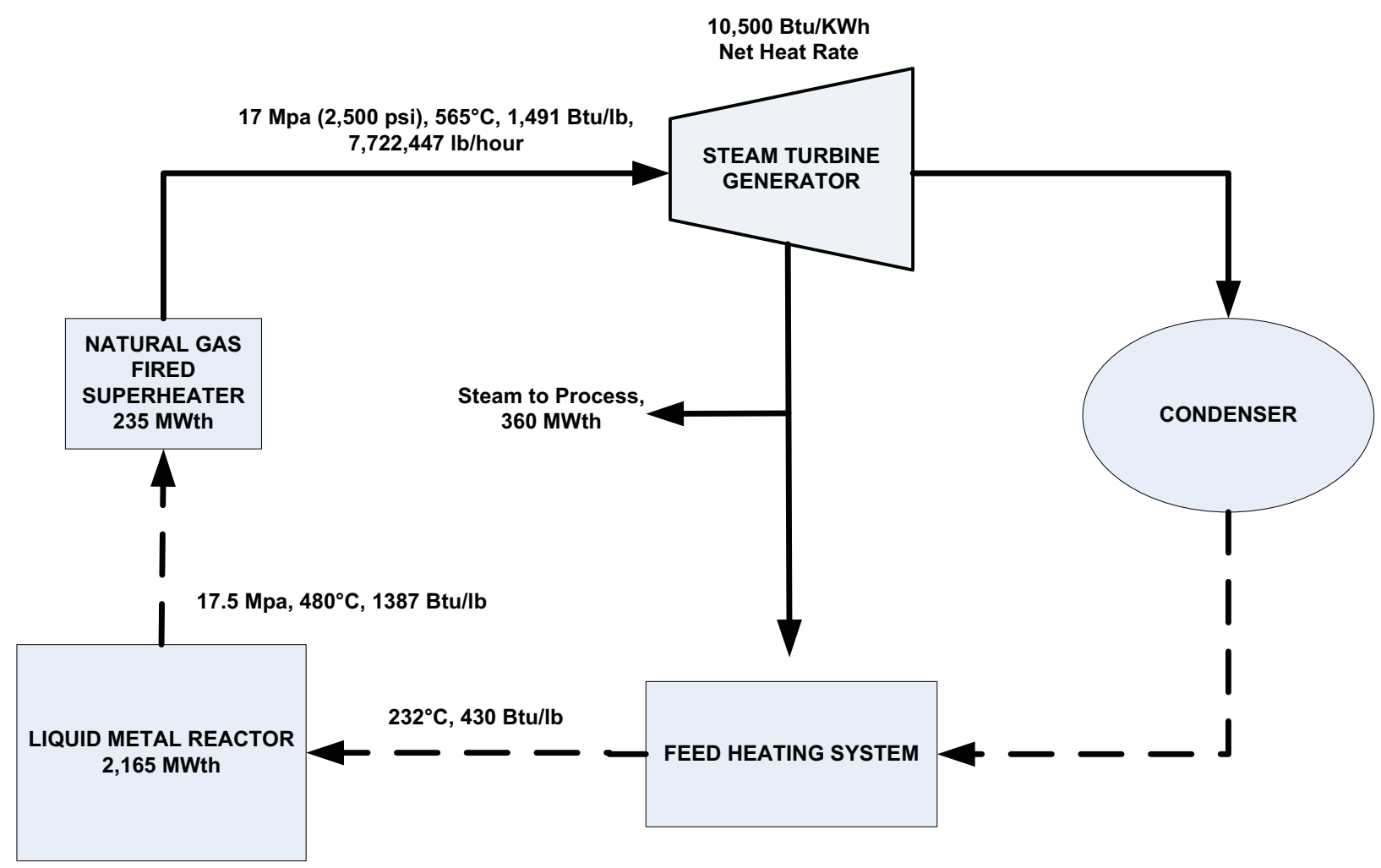

Figure 2. Application of an LMR steam generator with a natural gas fired superheater for steam and electricity production.

a. The cost of natural gas at which HTGR energy is comparable to that from a combined cycle gas turbine (CCGT) plant is in the range of $\$ 6$ to $\$ 7 / \mathrm{MMBtu}$ without a carbon tax, and $\$ 3$ to $\$ 4 / \mathrm{MMBtu}$ with a $\$ 50 / \mathrm{MT}$ carbon dioxide tax or cost of carbon sequestration. 


\subsubsection{Energy Cost Differences for LWR and LMR applications}

The effect of changes in the price of natural gas on the cost of co-generated electricity when applying a HTGR, LWR, or LMR in that application compared with the cost from a new combined cycle gas turbine (CCGT) plant is shown in Figure 3. These curves were developed assuming capital costs for the LWR and the LMR plants are comparable to that of the HTGR plant. As shown, the HTGR price is comparable to the price of a CCGT plant at a natural gas price in the range of $\$ 8$ to $\$ 9 / \mathrm{MMBtu}$; without any cost of carbon assessed against the CCGT plant. As shown in Figure 3, the price for the LWR application varies in a manner similar to the CCGT plant because the natural gas fired part of that plant provides most of the energy. For the LMR application, the effect is similar to that of the HTGR application because the natural gas plant provides less than $10 \%$ of the energy. In comparison with the HTGR the LMR price is comparable to that of the CCGT plant at $\sim \$ 11 /$ MMBtu instead of the $\sim \$ 8$ to $\$ 9 / \mathrm{MMBtu}$ for the HTGR plant, because of the addition of the natural gas fired heat exchanger to achieve the required steam superheat.

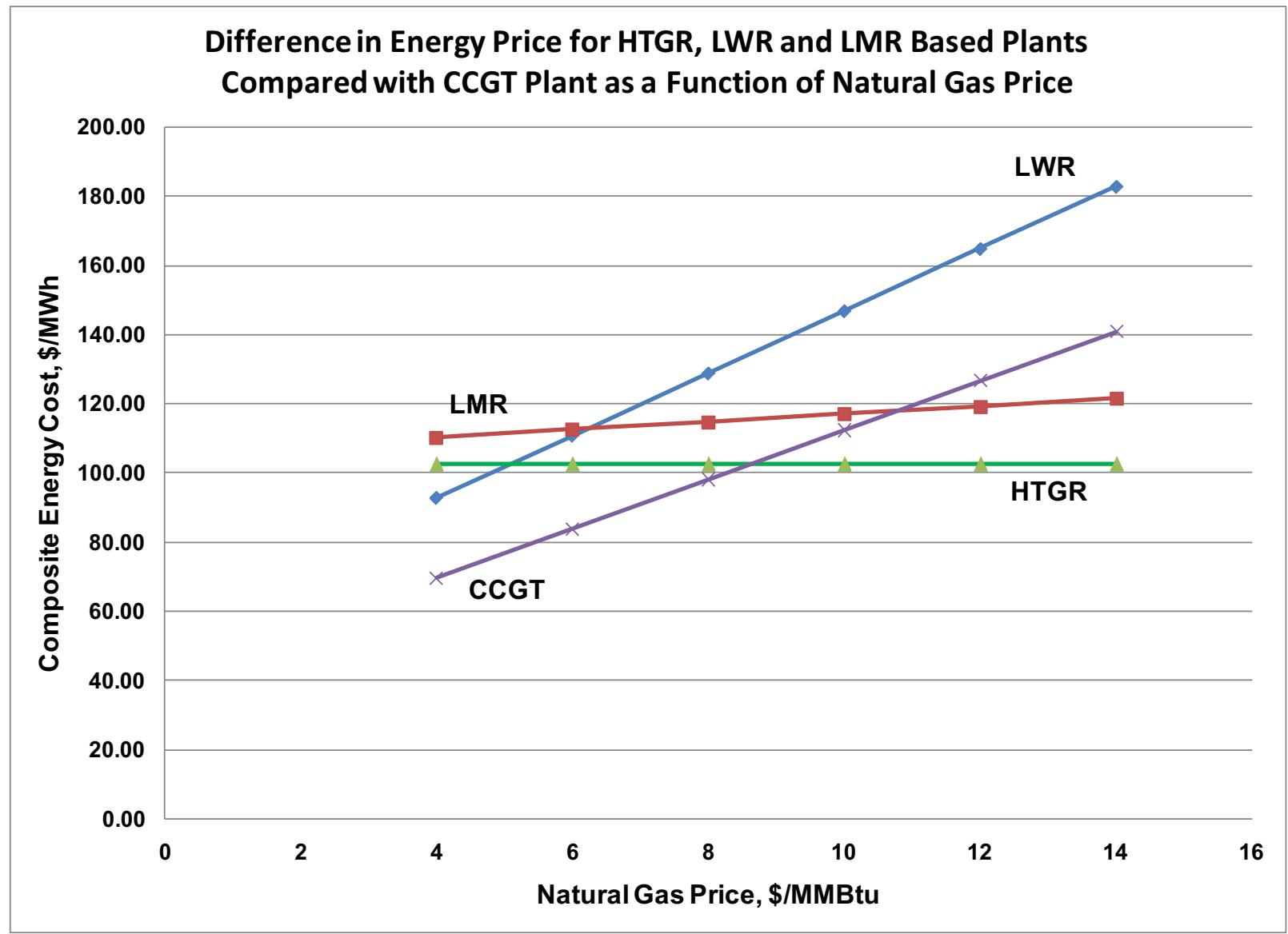

Figure 3. Effect of natural gas price on co-generated energy costs for LWR and LMR based plants compared with a CCTG plant.

\subsubsection{Molten Salt Reactor}

An MSR would be capable of achieving the steam pressure and temperature for this application similar to that of an HTGR. Better information on the cost of the MSR is needed to make a judgment on its economic competitiveness with the HTGR for co-generated steam and electricity. 


\subsection{High Temperature Gas Supply}

The use of LWR and LMR technologies to heat a secondary gas for application in selected industrial processes over the full range of 700 to $925^{\circ} \mathrm{C}$ needed to satisfy end user requirements needs supplemental heating by firing fossil fuels; typically, a natural gas or waste gas fired heat exchanger. The MSR technology could be used to achieve secondary gas temperatures up to about $850^{\circ} \mathrm{C}$ without supplemental heating. However, supplemental heating would be required to achieve the $925^{\circ} \mathrm{C}$ temperature required by end users. Figure 4 illustrates the application of all three technologies in generating a secondary gas supply temperature of $900^{\circ} \mathrm{C}$. The amount of energy that needs to be added in the natural gas fired heater increases, depending on the reactor technology applied (is highest for the LWR and lowest for the MSR). The HTGR technology is capable of supplying the full range of required secondary gas temperatures without any supplemental firing.

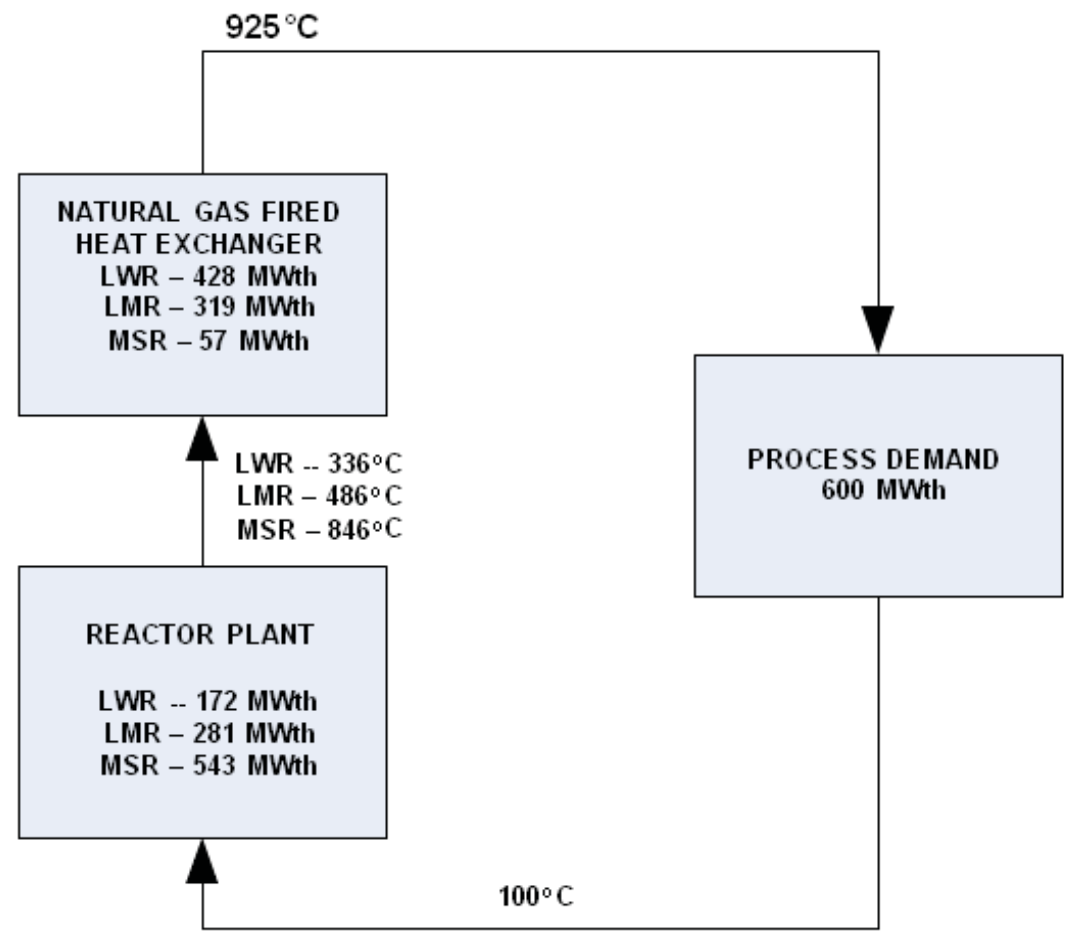

Figure 4. Application of LWR, LMR and MSR technologies to supply of high temperature secondary gas to an industrial process.

The following summarizes the variation in energy supplies by the reactor technologies and the natural gas fired heat exchanger for this application:

Table 2. Relative energy supplied from the reactor plant and the natural gas fired heat exchanger (600 MWth plant supplying $925^{\circ} \mathrm{C}$ gas).

\begin{tabular}{|l|c|c|}
\hline \multicolumn{1}{|c|}{ Reactor Technology } & Reactor Energy Input & $\begin{array}{c}\text { Natural Gas Fired Heat } \\
\text { Exchanger Energy Input }\end{array}$ \\
\hline Light Water Reactor & $28.6 \%$ & $71.4 \%$ \\
\hline Liquid Metal Reactor & $46.8 \%$ & $53.2 \%$ \\
\hline Molten Salt Reactor & $90.4 \%$ & $9.6 \%$ \\
\hline High Temperature Gas-cooled Reactor & $100 \%$ & $0 \%$ \\
\hline
\end{tabular}


Figure 5 shows the estimated prices for the high temperature gas (in $\$ / M M B t u$ delivered) for the use of LWR, LMR, MSR, and HTGR technology. A 600 MWth plant with varying reactor ratings as shown in Figure 4 and Table 2 was assumed. The comparison is with the HTGR. The capital costs of the LWR, LMR, and MSR plants were assumed to be similar to the HTGR capital costs for varying reactor module ratings. ${ }^{b}$ Figure 5 shows that the LWR and LMR cases could crossover with the HTGR for the assumed costs at very low NG prices. However, at natural gas prices above $\sim \$ 5 / \mathrm{MMBtu}$ the price of gas for these technologies is higher than for the HTGR.

The MSR operates at a peak reactor outlet temperature closely comparable to that of the HTGR $\left(860^{\circ} \mathrm{C}\right.$ compared with $\left.950^{\circ} \mathrm{C}\right)$. It therefore requires the smallest gas fired heat exchanger to achieve the required temperature. As shown in Figure 5 the addition of the natural gas fired heat exchanger increases the price of the high temperature gas by $\sim 13 \%$ for the MSR case compared with the HTGR supply.

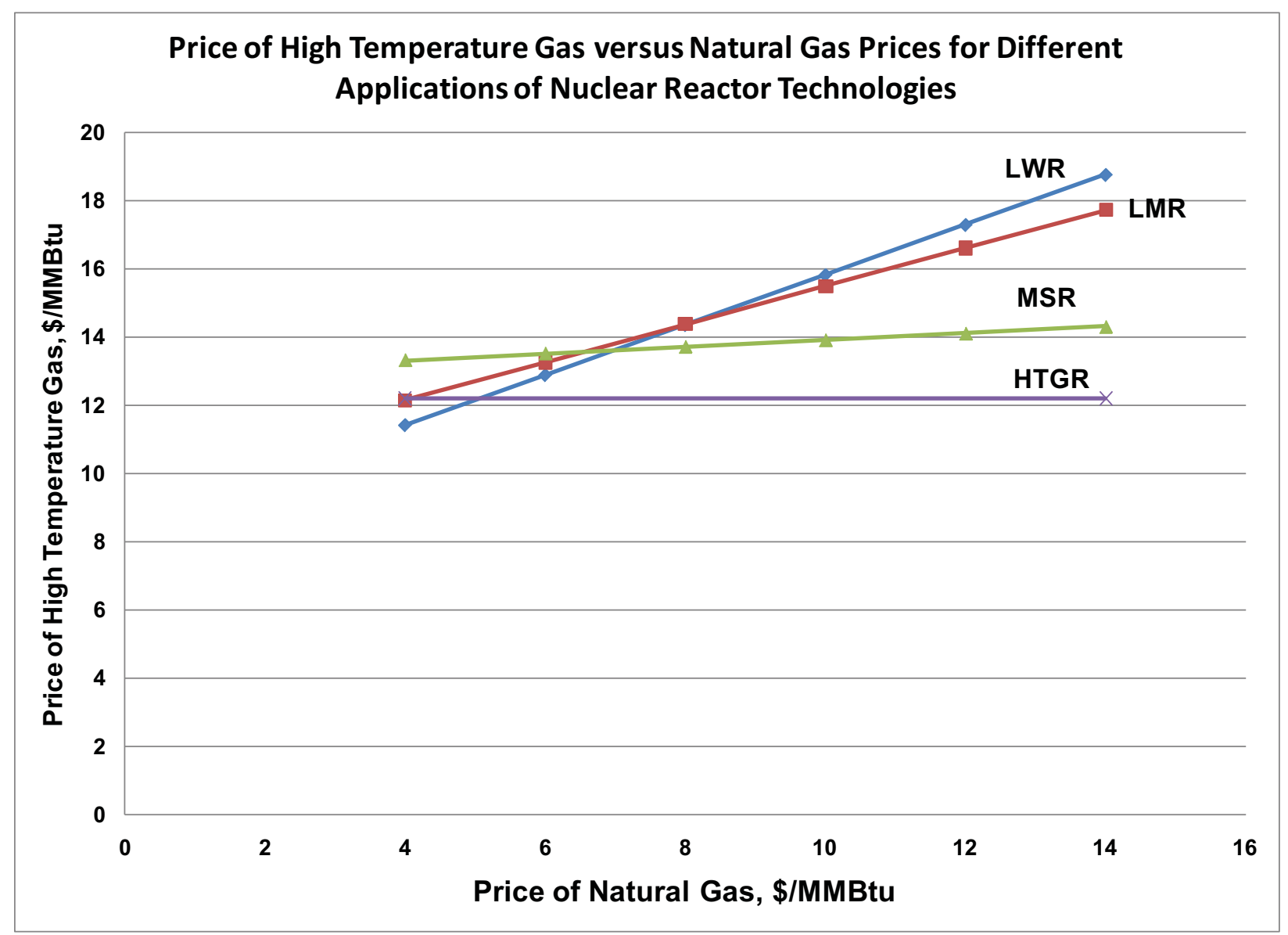

Figure 5. Comparison of the price of high temperature gas for different applications of nuclear reactor technologies.

b. There are considerable uncertainties with estimating the capital costs for each of these reactor technologies on a consistent basis because of the widely varying maturity of design information. The economics discussed herein are based on the same financial parameter assumptions used in INL/EXT-10-19037, High Temperature Gas-cooled Reactor Projected Markets and Preliminary Economics, July 2010. The results shown herein are representative and developed for comparative purposes and may differ from this study, principally because they use a finer correlation of reactor capital cost versus reactor rating and number of modules than used in prior studies. 


\section{CONCLUSIONS}

Use of the LWR technology as a source of high temperature process heat for producing steam and electricity or as a substitute for burning natural gas or waste gas to supply high-temperature gas in selected industrial processes is not practical nor economic.

Because the MSR and LMR operate at higher reactor outlet temperatures, they could be used in some of the applications that have been evaluated for the HTGR. The scoping economic analyses described herein, however, show that the addition of supplemental firing using natural gas or waste gas firing adds to the costs for these applications and makes them less attractive than the HTGR. The economics performed herein are based on assumptions of the capital costs for the LWR, LMR, and MSR technologies compared to an HTGR. ${ }^{\mathrm{c}}$ When those are developed beyond what is available at the time of this writing, additional evaluations could be performed to judge their economic viability compared the HTGR technology.

Even if the LMR and MSR technologies were evaluated to be economically comparable to the HTGR technology, there are other factors that diminish the attractiveness of these technologies in comparison with the HTGR technology, including:

- These technologies are not as fully developed as the HTGR technology. This represents a considerably higher risk in the time frame of interest of industrial end users.

- There are operational risks associated with use of these volatile and corrosive coolants when compared with the benign nature of helium in the HTGR.

- There are concerns with the practicality of using these technologies in general industrial energy supply applications. The liquid metal and molten salt coolants must be kept hot to prevent their "freezing" (solidification). This complicates the ability to maneuver and shut down these reactors to perform maintenance and refueling.

The HTGR has been shown to be technically and economically viable to supply high temperature energy to a wide range of industrial processes and should continue to be developed for this purpose.

\subsection{Prior Decisions Made on the NGNP Technology}

It is noted that the decision on the technology for high temperature process heat applications (HTGRs) was previously made based on the considerations summarized above. Utilization of HTGR technology for process heat applications has been addressed or confirmed in (1) DOE Road Maps, (2) the report, Design Features and Technology Uncertainties for the Next Generation Nuclear Plant, dated June 30, 2004, (3) the Mission Need Statement (CD-0), and (4) authorization of direct project funds expenditures for research and development, preconceptual design, trade studies, conceptual design under the Funding Opportunity Announcement and licensing in the amount of approximately $\$ 470$ million (through FY 2010) for developing NGNP gas reactor technology in collaboration with industry under Phase I of Energy Policy Act of 2005. Additionally, the combined DOE/Nuclear Regulatory Commission's Next Generation Nuclear Plant Licensing Strategy - A Report to Congress (issued in August 2008) confirms that the technology to be licensed for NGNP is the HTGR: "The DOE has determined that the NGNP nuclear reactor will be a very-high temperature gas-cooled reactor (VHTR) for the production of electricity, process heat, and hydrogen." Hence, the decision for the technology for high temperature process heat applications has been firmly established.

c. Ibid. 
The Idaho National Laboratory supports a continuing discussion on the best reactor technology for specific purposes, and welcomes confirmation of previous evaluations such as summarized above. The NGNP Project has been executed on the basis that the primary interests of industry need to continue to be fulfilled - reducing carbon footprint with an energy source that reduces volatility in the energy prices experienced over the last decade and improves security of the energy source. Concepts such as LWRs, MSRs, and LMRs need to be evaluated on their technical and economic merits (whether in a small modular or other configuration) and a determination made of their capabilities for industrial applications. 